\title{
Precipitating antibodies to cellular antigens in Sjögren's syndrome, rheumatoid arthritis, and other organ and nonorgan-specific autoimmune diseases
}

\author{
MARGARET A. ALSPAUGH, ${ }^{1}$ W. WATSON BUCHANAN, ${ }^{2}$ AND \\ KEITH WHALEY ${ }^{3}$
}

From the Section of Rheumatology, Louisiana State University Medical Center, New Orleans, ${ }^{1}$ USA; t Centre for Rheumatic Diseases, ${ }^{2}$ Glasgow; and Department of Pathology, Western Infirmary, ${ }^{3}$ Glasgo $\frac{\$}{2}$, Scotland

SUMMARY The prevalence of three precipitating antibodies, anti-SS-A, anti-SS-B, and rheumatoid arthritis precipitin (RAP), reacting with an extract of the human lymphoid cell line Wil ${ }_{2}$, w多s studied in the sicca syndrome, Sjögren's syndrome with rheumatoid arthritis, rheumatoid arthrit\$, various seronegative spondyloarthritides, and organ and nonorgan-specific autoimmune disease. Anti-SS-A and anti-SS-B occurred most frequently in the sera of patients with the sicca syndronie, whereas RAP occurred most frequently in seropositive rheumatoid arthritis sera. However, the data did not support previous studies where patients with sicca syndrome had a high incidence $\%_{0}^{\circ}$ anti-SS-A and/or -SS-B antibodies but had a low frequency of RAP, and patients with Sjögrens syndrome in association with rheumatoid arthritis had a high incidence of RAP but a low incidenge of anti-SS-A and/or -SS-B. Instead the three antibodies were present in both forms of Sjögremo syndrome. This suggested a difference in the diseases in the UK compared to the USA, or that these antibodies do not have the more subtle diagnostic specificity that was originally suggested.ळे

Sjögren's syndrome, like the other connective tissue diseases, is a multisystem disorder (Whaley et al., 1973a) and is associated with a variety of immunological peculiarities including hypergammaglobulinaemia, a high incidence of serum autoantibodies (Whaley et al., 1973b), impaired cell-mediated immunity (Levanthal et al., 1967; Whaley et al., 1971), and an unusual predisposition to develop malignant lymphoproliferation (Anderson and Talal, 1973; Whaley et al., 1973b). Recently three new precipitating antigen-antibody systems in Sjögren's syndrome have been described, the antigens being contained in an extract of the $\mathrm{Wil}_{2}$ human lymphoblastoid cell line (Alspaugh and Tan, 1975). Two antibodies, anti-SS-A and anti-SS-B, were found to occur almost exclusively in the sera of patients with the sicca complex of Sjögren's syndrome, while the third, the rheumatoid arthritis precipitin (RAP), was found almost exclusively in the sera of patients having rheumatoid arthritis with Sjögren's syndrome or seropositive rheumatoid arthritis alone (Alspaugh et al., 1976). Since the prevalence of other auto-

Accepted for publication August 10, 1977

Correspondence to Dr K. Whaley, Department of Pathology, Western Infirmary, Glasgow G11 6NT antibodies in Sjögren's syndrome differs between patients from the UK and the USA, our Glasgo $\overline{\mathrm{ow}}$ patients were examined for the prevalence of these precipitins. In addition, the sera of patients with various well-documented seronegative spondyloarthritides or organ-specific autoimmune diseases were also examined for these precipitating antibodges since most of these diseases had not been studied previously.

\section{Materials and methods}

Sjögren's syndrome was diagnosed by previousily described criteria (Whaley et al., 1973a). 23 patients had only the sicca syndrome, 39 had Sjögrenoss syndrome with rheumatoid arthritis, and 3 had fire sicca syndrome associated with lymphoma: 1 reticulum cell sarcoma, 1 lymphosarcoma, and ${ }^{\circ} 1$ Hodgkin's disease. Rheumatoid arthritis (Ropesient al., 1958), Reiter's syndrome, ankylosing spondylitis, psoriatic arthritis, osteoarthrosis, pernicigis anaemia, Hashimoto's thyroiditis, thyrotoxicosis, simple goitre, and primary biliary cirrhosis wofe diagnosed using standard clinical, radiological, aftd laboratory criteria. 60 sera from geriatric patients 
over 80 years of age were included in the study: none of these had rheumatoid arthritis, or other connective tissue diseases, although keratoconjunctivitis was a common finding (Whaley et al., 1972). 71 sera from healthy US hospital personnel were included as controls. The number of patients in each group is shown in Tables 1-3.

The antigen used in the system was an extract of the $\mathrm{Wil}_{2}$ human lymphoblastoid cell line, and precipitating antibodies to various antigens in this extract were detected by double diffusion in agarose as previously described (Alspaugh and Tan, 1975).

\section{Results}

SJÖGREN'S SYNDROME (TABLE 1)

Five of $23(22 \%)$ sera from patients with the sicca syndrome were found to contain anti-SS-A, 9 of 23 (40\%) contained anti-SS-B, and 7 of $23(30 \%)$ RAP. None of the 7 with RAP had clinical or radiological evidence of rheumatoid arthritis. Of the sera from patients with Sjögren's syndrome with rheumatoid arthritis, 6 of $39(15 \%)$ contained anti-SS-A, 3 of $39(8 \%)$ contained anti-SS-B, and 15 of $39(38 \%)$ contained RAP. 2 of 3 sera $(67 \%)$ from patients with the sicca syndrome complicated by lymphoma contained both anti-SS-A and anti-SS-B; RAP was not detected. Anti-SS-A and anti-SS-B were not found in any of the normal control sera, but RAP was found in 6 of $71(8 \%)$. In the geriatric group, 1 of $60(2 \%)$ had anti-SS-A, and 5 of $60(8 \%)$ had RAP, whereas none had anti-SS-B. The patient with anti-SS-A had keratoconjunctivitis sicca but not xerostomia.

INFLAMMATORY ARTHRITIDES (TABLE 2)

RAP was found in 19 of $29(65 \%)$ sera from patients with seropositive, but only in 5 of $30(17 \%)$ patients with seronegative rheumatoid arthritis. Anti-SS-A and anti-SS-B were not detected in any of the seronegative spondyloarthritic sera. RAP was found in only a low variable prevalence, ranging from $10 \%$ in the psoriatic arthritis or osteoarthrosis patients

Table 1 Prevalence of precipitating antibodies in Sjögren's syndrom?

\begin{tabular}{lllll}
\hline Disease & $\begin{array}{l}\text { No. of } \\
\text { sera tested }\end{array}$ & anti-SS-A & anti-SS-B & RAP \\
\hline $\begin{array}{l}\text { Sicca syndrome } \\
\begin{array}{l}\text { Sicca syndrome with } \\
\text { lymphoma }\end{array}\end{array}$ & 23 & $5(22 \%)$ & $9(40 \%)$ & $7(30 \%)$ \\
$\begin{array}{l}\text { Sjögren's syndrome } \\
\text { with rheumatoid }\end{array}$ & 39 & $2(67 \%)$ & $2(67 \%)$ & 0 \\
$\begin{array}{l}\text { arthritis } \\
\begin{array}{c}\text { Normal controls } \\
\text { (USA) }\end{array}\end{array}$ & 71 & $6(15 \%)$ & $3(8 \%)$ & $15(38 \%)$ \\
\begin{tabular}{l} 
Geriatric sera \\
\hline RAP
\end{tabular} & 60 & $1(2 \%)$ & 0 & $6(8 \%)$ \\
\hline
\end{tabular}

$\mathbf{R A P}=$ rheumatoid arthritis precipitin. to $18 \%$ in Reiter's syndrome. Since there was an incidence of $8 \%$ in the normal population, $10 \%$ in psoriatic or osteoarthrosis is not significant.

OTHER AUTOIMMUNE DiSEASES (TABLE 3)

Simple goitre was the only one of the organ-specific autoimmune diseases with a significant prevalence of any of the antibodies, RAP being found in 7 of $20(35 \%)$ sera. The sera of 2 of these patients contained rheumatoid factor in titres greater than $1 / 80$, using the RA latex test. In primary biliary cirrhosis associated with keratoconjunctivitis sicca there was a low prevalence of anti-SS-A of 1 of $9(11 \%)$, and RAP of 2 of $9(22 \%)$, whereas no antibodies were detected in any sera from primary biliary cirrhosis without associated keratoconjunctivitis sicca.

\section{Discussion}

The prevalence of three precipitating autoantibodies found in the sera of patients with Sjögren's syndrome was investigated. As in previous studies (Alspaugh et al., 1976), anti-SS-A and anti-SS-B were found most commonly in the sera of patients with the sicca syndrome, although the prevalence of these two antibodies in this disease was lower in the present study. This finding is not unexpected as previous studies have shown that patients with the

Table 2 Prevalence of precipitating antibodies in various arthritides

\begin{tabular}{llllr}
\hline Disease & $\begin{array}{l}\text { No. of } \\
\text { sera tested }\end{array}$ & anti-SS-A & anti-SS-B & RAP \\
\hline RA, seropositive & 29 & $1(3 \%)$ & 0 & $19(65 \%)$ \\
$\begin{array}{l}\text { RA, seronegative } \\
\text { Psoriatic arthritis }\end{array}$ & 30 & 0 & 0 & $5(17 \%)$ \\
$\begin{array}{l}\text { Ankylosing } \\
\quad \text { spondylitis }\end{array}$ & 24 & 0 & 0 & $1(10 \%)$ \\
$\begin{array}{l}\text { Reiter's syndrome } \\
\text { Osteoarthrosis }\end{array}$ & 11 & 0 & 0 & $4(16 \%)$ \\
$\begin{array}{l}\text { Normal controls } \\
\text { (USA) }\end{array}$ & 29 & 0 & 0 & $2(18 \%)$ \\
\hline
\end{tabular}

Table 3 Prevalence of precipitating aniibodies in organ specific autoimmune diseases

\begin{tabular}{|c|c|c|c|c|}
\hline Disease & $\begin{array}{l}\text { No. of } \\
\text { sera tested }\end{array}$ & anti-SS-A & anti-SS-B & $\boldsymbol{R A P}$ \\
\hline \multicolumn{5}{|l|}{ Hashimoto's } \\
\hline Thyrotoxicosis & 20 & 0 & 0 & $1(5 \%)$ \\
\hline Simple goitre & 20 & 0 & $\mathbf{0}$ & $7(35 \%)$ \\
\hline Pernicious anaemia & 20 & 0 & 0 & 0 \\
\hline $\begin{array}{l}\text { Primary biliary } \\
\text { cirrhosis with } \\
\text { keratoconjunctivitis } \\
\text { sicca }\end{array}$ & 9 & $1(11 \%)$ & 0 & $2(22 \%)$ \\
\hline $\begin{array}{l}\text { Primary biliary } \\
\text { cirrhosis without } \\
\text { keratoconjunctivitis }\end{array}$ & & & & \\
\hline sicca & 10 & 0 & 0 & $\mathbf{0}$ \\
\hline $\begin{array}{l}\text { Normal controls } \\
\text { (USA) }\end{array}$ & 71 & 0 & 0 & $6(8 \%)$ \\
\hline
\end{tabular}


sicca syndrome in the USA have a higher prevalence of most autoantibodies, with the exception of gastric parietal cell antibody, than sicca syndrome patients in the West of Scotland. This is thought to reflect milder disease in the Glasgow patients (Whaley et al., 1973b). Apart from the sicca syndrome, anti-SS-A and anti-SS-B were found in patients with keratoconjunctivitis sicca (Sjögren's syndrome with rheumatoid arthritis, 1 geriatric patient with keratoconjunctivitis sicca; 1 patient with primary biliary cirrhosis and keratoconjunctivitis sicca), except in one instance, a patient with seropositive rheumatoid arthritis who had no clinical evidence of Sjögren's syndrome.

RAP was present in the sera of $65 \%$ of patients with seropositive rheumatoid arthritis, and was found in $10 \%$ to $18 \%$ of sera from patients with seronegative rheumatoid arthritis, osteoarthrosis, or spondyloarthritis. Unexpectedly, RAP was detected in the sera of $30 \%$ of patients with the sicca syndrome, which is in marked contrast to previous results (Alspaugh et al., 1976). None of the latter patients had evidence of arthritis. Of the remaining organ and nonorgan-specific autoimmune disease studies, there were two findings of interest. First, the prevalence of RAP in simple goitre was $35 \%$. This observation at present is unexplained, although there is an increased prevalence of thyroid autoantibodies in this condition (Doniach et al., 1960), which shows that simple goitre is associated with autoimmune phenomena. The sera of 2 of these patients contained rheumatoid factor which, of course, occurs in diseases other than rheumatoid arthritis. Secondly, $22 \%$ of patients with the combination of primary biliary cirrhosis and keratoconjunctivitis sicca had RAP in their sera, whereas RAP was absent in the sera from patients with primary biliary cirrhosis without evidence of Sjögren's syndrome. The low prevalence of these precipitins in the sera from geriatric patients is somewhat unexpected as most other autoantibodies increase with age (Whaley et al., 1971).

In summary, the presence of anti-SS-A and/or -SS-B precipitins in serum supports a diagnosis of Sjögren's syndrome. RAP was generally confined to the inflammatory arthritides and occurred most frequently in seropositive rheumatoid arthritis. Previous studies have shown that the incidence of RAP was very low in other connective tissue diseases (Alspaugh et al., 1976); and in this study, with the exception of simple goitre, the incidence in organspecific diseases was less than in the normal population suggesting that RAP is most likely an antibody related to seropositive rheumatoid arthritis. However, in contrast to previous studies on Sjögren's syndrome (Alspaugh et al., 1976) where
anti-SS-A and/or -SS-B were found primarily if sicca syndrome and RAP was found in rheumatord arthritis or Sjögren's syndrome with associate rheumatoid arthritis, these three antibodies did nef segregate patients into two types of Sjögren's syres drome. Instead all three antibodies were found $\overline{\underline{\underline{m}}}$ both types of Sjögren's syndrome. This difference may be due to variations in patient population ang severity of the disease in the UK compared to the USA, or these antibodies may not have the move subtle diagnostic specificity originally suggested. $\overrightarrow{\vec{H}}$

The pathogenetic significance of these antigew antibody systems is currently unknown. The identification of the antigens is important, as the antigen preparation we used was obtained from $:$ I continuous cell line. If any of these antigens actest restricted to certain cell lines, in vitro, then the demonstration of these antibodies in the sera of patients with Sjögren's syndrome or rheumatoa arthritis will have opened an important line $\overrightarrow{\text { of }}$ research into the aetiology of these diseases.

\section{References}

Alspaugh, M. A., and Tan, E. M. (1975). Antibodies to cellular antigens in Sjögren's syndrome. Journal of Clinical Investigation, 55, 1067-1073.

Alspaugh, M. A., Talal, N., and Tan, E. M. (1976). Differe tiation and characterization of autoantibodies and the antigens in Sjögren's syndrome. Arthritis and Rheumatis 19, 216-222.

Anderson, L. G., and Talal, N. (1972). The spectrum $\overrightarrow{\theta f}$ benign to malignant lymphoproliferation in Sjögren syndrome. Clinical and Experimental Immunology, 199-221.

Doniach, D., Hudson, R. V., and Roitt, I. M. (1960). Human autoimmune thyroiditis: clinical studies. British Mediced Journal, 1, 365-372.

Leventhal, B. G., Waldorf, D. S., and Talal, N. (196혀. Impaired lymphocyte transformation and delayed hyper: sensitivity in Sjögren's syndrome. Journal of Clinical Investigation, 46, 1338-1345.

Ropes, M. W., Bennett, G. A., Cobb, S., Jacox, R. F., and Jessar, R. A. (1958). Diagnostic criteria for rheumatopd arthritis. Bulletin on Rheumatic Diseases, 9, 175-176.

Whaley, K., Glen, A. C., MacSween, R. N. M., Deodaw, S. D., Dick, W. C., Nuki, G., and Buchanan, W. (1971). Immunological responses in Sjögren's syndronfe and rheumatoid arthritis. Clinical and Experimental Immunology, 9, 721-731.

Whaley, K., Williamson, J., Wilson, T., McGavin, D. D. M, Hughes, G. R. V., Hughes, H., Schmulian, L. R., MacSween, R. N. M., and Buchanan, W. W. (197श Sjögren's syndrome and autoimmunity in a geriatejc population. Age and Aging, 1, 197-206.

Whaley, K., Williamson, J., Chisholm, D. M., Webb, $\&_{0}$ Mason, D. K., and Buchanan, W. W. (1973a). Sjögren's syndrome. I. Sicca components. Quarterly Journal f Medicine, 42, 279-302.

Whaley, K., Webb, J., McAvoy, B. M., Hughes, G. R. Lee, P., MacSween, R. N. M., and Buchanan, W. (1973b). Sjögren's syndrome. 2. Clinical associations am immunological phenomena. Quarterly Journal of Medicing, 42, 513-548. 